\title{
Law of Negligence: Duty of Care, Standard of Care, and the Notion of Personal Responsibility
}

\author{
Qiang He, Jia-Ling Feng, Wan-Yun Huang \\ College of Management, Tianjin University of Traditional Chinese Medicine, Tianjin, China \\ E-mail: heqiangmail@126.com, taohuixin.0508@163.com
}

\begin{abstract}
This essay's main body divides into two parts. After a brief background of the historical development of the law of negligence, the first part is to demonstrate the principles of Duty of Care and the Standard of Care, including duty of care for negligent acts and the guidelines of breaching the standard of care. Then it will analyze the special duty of care within parent and child from three aspects. Finally the essay will provide a conclusion to summarize all the information above and give a clearly understand of duty of care for negligence.
\end{abstract}

Keywords-duty of care; standard of care; the notion of personal responsibility

\section{INTRODUCTION}

Tort law is considered as an important branch of civil law. It represents a 'wrong' act or omission by the defendant which actually caused the plaintiff's loss or injuries (Pentony, Graw, Lennard, \& Parker, 2008). Negligence is one of the most significant legislative components in tort law. It is always considered as four divisions: the defendant must owe a duty of care to the plaintiff; the duty must be breached by the defendant; the breach must cause loss or injury suffered by the plaintiff; and the damage must not remoteness (Richards, Ludlow, \& Gibson, 2009).

However, people discuss the legislation and have different opinions on the simple 'accident' and 'personal responsibility'. Some of them argue that if an innocent person is injured nowadays, someone else, no matter it to be another person, a corporation or the government, will be blamed for it. Others argue that the situation is not that simple in real world and that the concept of 'personal responsibility' still exists in law.

Accordingly, the purpose of this academic essay is to illustrate the Duty of Care (i.e. the 1st essential) and Standard of Care (i.e. the 2nd essential) essentials of negligence in detail and critical analyzing a specific aspect on parent's duty to child and third parties. It will provide strong evidences with case authorities and secondary authorities to support the statement as well.

This essay's main body divides into two parts. After a brief background of the historical development of the law of negligence, the first part is to demonstrate the principles of Duty of Care and the Standard of Care, including duty of care for negligent acts and the guidelines of breaching the standard of care. Then it will analyze the special duty of care within parent and child from three aspects. Finally the essay will provide a conclusion to summarize all the information above and give a clearly understand of duty of care for negligence.

\section{BACKGROUND}

The tort of negligence is a vital aspect of the tort law, because compare to other tort, there is a large amount of negligence cases occurred in real life than others (Davies \& Malkin, 2008). Before the landmark case of Donohue $v$ Stevenson [1932], most of the counts did not consider similar cases as negligence (Barravecchio, 2013).

Since the 1980s, there was a development of negligent advice in Australia with the case Shaddock and Associates v. Parramatta City Council (1981) 150 CLR 225. And there were important legislative changes during the 2002-03 periods. After these kinds of improvements, negligence plays a more important role in recent years.

\section{DUTY OF CARE FOR NEGLIGENT ACTS}

The tort of negligence states that a reasonable person who caused another person's loss or injury because she or he fails to take reasonable care should provide compensation (Howe, Walsh, \& Rooney, 2012). A negligence action is determined by three key issues:

- The defendant must owe a duty of care to the plaintiff;

- The defendant must breach the duty of care; and

- The defendant's acts or omission must cause the plaintiff's loss or injury.

In order to determine the duty of care for different cases, people usually consider it from two ways which named historical approach and contemporary approach (Pentony, Graw, Lennard, \& Parker, 2008). According to these two approaches, people can easily identify the duty of care.

\section{A. Historical Approach}

The established historical test to identify a duty of care for negligence act is Donoghue v Stevenson [1932] AC 562. In this case, the manufacturer of the ginger beer did owe the plaintiff a duty of care, and because of the snail in the bottle the plaintiff suffered 'nervous shock and severe gastro-enteritis', the defendant should response this negligence act and recovered compensation.

It also stated the two components of duty of care, 'reasonable foreseeability' and 'proximity', in the same case. As Trindade, Cane and Lunney (2007) said, for reasonable foreseeability, people will consider that in a particular situation, does the reasonable person foresee a loss or injury 
of the plaintiff resulted from the defendant's behavior? On the other hand, for proximity, does the defendant know his or her negligent act may affect the plaintiff because of the closeness?

Furthermore, Richards, Zwart and Ludlow (2013) use an example which provided by Hayne $\mathbf{J}$ to explain proximity as "nearness, hearness or dearness": Tame v New South Wales; Annetts v Australian Stations Pty Ltd (2002) 211 CLR 317 at [25-26]. The best way to find out a duty of care existed is to consider the relationship between the parties and the relevant proximity to the negligent conduct.

All in all, both of the two elements do not mean the defendant ought to be actually foreseen the plaintiff's results. However, what the defendant should know is that aware the effects of doing the negligent act (Trindade, Cane \& Lunney, 2007).

\section{B. Contemporary Approach}

In order to change their decided method from a 'one-best' approach to a 'broad approach', the High Court decided to impose a new approach in the establishment of a duty of care due to a number of cases in the 1990s. They were not satisfied with 'proximity' because it was not suitable for the defining test to identify a duty of care in any significant cases (Pentony, Graw, Lennard, \& Parker, 2008). Instead, the High Court expressed four rules to achieve more correct identify of a duty of care.

1) Reasonable foreseeability:

The question of reasonable foreseeability is a basic question of whether the duty of care is owed. It is always the first question asked in negligence. Chapman v Hearse (1961) is the sample of this test. Besides, one of the most famous cases which considered as unforeseeable plaintiff is Palsgraf $\mathrm{V}$ Long Island R R Co 248 NY 339 (1928) (US).

For this aspect, the courts should determine that if there was a reasonable foreseeability risk of damage, such as injury or loss. In other words, if there was not a reasonable foreseeability, it could not be established the existence of a duty of care (Howe, Walsh, \& Rooney, 2012). It is an important essential of contemporary approach.

2) Analogies - recognized duties of care

In this method, the courts would review the previously cases to figure out whether or not the present case is similar to one of the established duty of care (Richards, Ludlow, \& Gibson, 2009). For example, employers owe a duty of care to their employees, the driver of a motor vehicle owes a duty of care to other road users, and schools owe a duty of care to the students and so on. Depending on the judgments of those previous cases, it is helpful for the courts to make decisions of the analogous cases, especially for general duty of care, such as professionals to clients and manufacturers to customers. In other words, this approach is basically classified cases into established categories, and then considers the decisions with actual circumstances.

\section{3) Neighbourhood factors}

If there are not analogous cases, the courts would consider the significant factors of the case to work out the duty of care. Under this situation, Pentony, Graw, Lennard, \& Parker
(2008) stated that they try to identify a 'neighbourhood' relationship according to four features:

- The plaintiff's vulnerability,

- The plaintiff's reliance on the defendant,

- The defendant's assumption of responsibility, and

- The defendant's control of their behavior.

When the Court cannot identify a case into an established category, they can consider the vulnerability of the plaintiff, whether or not the plaintiff is disadvantaged comparing with the defendant in this matter. Does the plaintiff rely on the defendant, or the defendant's assumption of responsibility (if any)? Then what is the level of the defendant to control their actions? After considering the four questions, the Court will get a sufficiently close 'neighborhood' relationship existed to recognize a duty of care.

4) Social policy

Social policy may sometimes against the established duty of care in some situations. In other words, the defendant may owe a liability of legal policy.

There are various forms of policy, which range from legally recognized policies to a particular judge's personal values. Therefore, judges should be quite cautious about interfering with government policies. In Miller v Miller (2011), the Court noticed that public policy means people should not allow illegal behavior, but in this case they particularly focus on the determination of whether the duty of care should be arise due to the detail and relationship between the parties (Sappideen, Vines, \&Watson,2009).

Accordingly, this aspect allows the courts to compete with the considerations of social policy and then determine a duty of care should or not be used (Howe, Walsh, \& Rooney, 2012).

\section{STANDARD OF CARE}

Once the facts of the case confirm that the defendant owes the plaintiff a duty of care, it does not mean the defendant's action result in damage or loss. Therefore, the plaintiff needs to provide more evidence to prove their statements. Hence, the next step is considering the second essential of negligence, breach of Standard of Care. Richards, Ludlow and Gibson (2009) summarized that in order to determine the breach of Standard of Care, there are two issues to consider:

- the extent of foreseeable risk that created by the defendant's conduct;

- the reasonableness or otherwise of the defendant's response to that risk.

\section{A. Requisite standard: that of a reasonable person}

The standard of care is determined by comparing a notional reasonable person's actions or omissions with the defendant's conducts in the same circumstances. The 'reasonable person' is not a specific or real person. It is an imaginary benchmark or device used by the courts (Sappideen, Vines, \&Watson, 2009).

Accordingly, the reasonable person should be examined the two attributes. Firstly, there is a presumption of average intelligence, which is used to test the defendant's intelligence (Bagaric, Faris \& Carter, 2011). If the defendant's 
intelligence is higher than the average level, then this person is not judged according to above average intelligence. Otherwise, if the defendant has a lower intelligence, the person has to follow the standard average intelligence.

Furthermore, the standard of care may also be variable based on personal characteristics of the defendant, such as the level of experience. But it would always be an objective test based on board characteristics (Richards, Ludlow \& Gibson, 2009).

\section{B. Has the Standard been breached?}

After considering the reasonable person in a specific circumstance, the courts need to identify how the defendant breaches the duty of care. Thus, the courts established several guidelines to determine a breach in the standard of care. In this essay, we list five guidelines as follow:

\section{1) Probability of harm:}

Refer to Bolton v Stone [1951] AC 850, the probability of harm guideline states that the greater the probability of harm, the greater amount of care which has to be taken (Bagaric, Faris \& Carter, 2011). It means if there is a high level risk of harmful injury or loss, the greater the standard of care that would be shown by a reasonable person with a higher probability of a breach.

\section{2) Seriousness of possible injury}

The second guideline is based on Paris v Stepney Borough Council [1951] AC367. This guideline states that the more serious the possible consequences of injury, the greater the degree of care which has to be shown (Howe, Walsh, \& Rooney, 2012). In other words, a greater likelihood of serious injury will lead to the greater the probability of a breach if the reasonable person does not exercised the duty of care.

3) Costs and difficulties of avoiding or reducing the risk This guideline establishes that when the cost and difficulty of avoiding the risk is small and the actual risk is great, then there is a greater likelihood of a breach if the reasonable person does not take remedial actions (Bagaric, Faris \& Carter, 2011). In other words, the defendant can take actions to avoid the risk but he did not do that, which leads to a big damage or loss, the situation should be considered as a breach.

\section{4) Value of the defendant's conduct}

The guideline states that if the defendant's conduct leads to less social or economic value, then the likelihood of a breach in the standard of care will be great (Luntz \& Hambly, 2002). This rule is typically relevant to the social responsibility. If someone's action results in a decrease of social or economic value, it can be considered as the people owe liability to the society. Thus, it is a greater likelihood that the person breaches the standard of care.

5) 4.2.5 Conformity with established standards

The final one shows that it is very important to keep conformity with any established standards, and vice versa (Richards, Ludlow, \& Gibson, 2009). It means no matter in any trade or profession, the reasonable care is exercised as important evidence and will always conformity with established standards.

\section{ANALYSIS}

After considering the general principles of duty of care, there are still some special duty of care situations, such as educational authority to pupils, medical practitioner to patient and transferor to premises (Richards, Zwart \& Ludlow, 2013). The second part of this essay will pay attention to a particular situation, discussing parent's duty to child and third parties. Generally parents do not owe duty to a child in respect of feeding and clothing and "raising" (Rogers v Rawlings [1969] Qd R 262), but they will owe a duty which may result in danger or high risk situations to their child (Sappideen, Vines, \&Watson, 2009).

\section{A. General duty to child}

As regards parent's liability to their child, Richards, Zwart and Ludlow (2013) said there is no doubt that a parent should liable for their negligent acts which might lead to injury to their children. However, the Australian law does not have any principle of parental immunity while the Supreme Court of New South Wales stated not only focus on the relationship of parent and child, but also the particular situation.

In order to deal with the complex circumstance, some relevant factors need to be provided, including the control level of parent over the child, the dependence and vulnerability of the child, the foreseeable injury and other factors which required by the modern law of negligence (Sappideen, Vines, \&Watson, 2009).

However, it does not mean a parent should liable the child any general duty of care to control all activities. A typical case in this situation is Robertson v Swincer (1989) 52 SASR 356. In this case, the damage is not caused by the child itself, but by a third party. Thus, the third party, instead the parent, is liable for the damage.

\section{B. Specific duty to child}

A parent's general duty of care to the child does not state such a situation that the parent's negligent acts hurt the child. Therefore, the Court needs a specific duty of care to analyze cases.

In Rogers v Rawlings [1969] Qd R 262, a child was injured when she was skiing water. The Court found out that the mother had failed to supervise her daughter adequately and to remind the driver of the boat of the inexperienced child. Whilst, depending on her position of knowledge, Rawlings of course owed duty of care in this situation.

The rule is not limited to parents. It could be anyone who has care of the child, like babysitter (Richards, Zwart \& Ludlow, 2013). The key issue of this rule is to figure out who takes the responsibility to look after the child, either the parent or the caregiver.

\section{Duty to protect third parties}

This aspect discusses whether or not a parent owes a duty of care to protect the third parties from the negligent actions of their children (Sappideen, Vines, \&Watson, 2009).

In Smith v Leurs (1945) 70 CLR 256, the High Court recognized the parents taught their child how to play a slingshot but failed to warn the dangerous of this activity. Then the child caused the plaintiff's injury. Accordingly, the 
High Court considered that it was sufficient for the parents to response for the duty of care.

Nevertheless, the High Court state that the liability may only be established on personal fault on the parent's part. Thus, the duty definitely exists, but the standard of care is not complex and stands behind of a school authority (Richards, Zwart \& Ludlow, 2013).

\section{CONCLUSION}

In conclusion, this essay aims to put a clear description on negligence of tort law in Australia, especially the first and second essentials. And as a critical analysis on a special duty of care situation, which is the parent's duty of care to child and third parties, the essay introduces the basic information and supplies arguments of the test.

The first essential of negligence is duty of care. It is also the first step for a successful negligence process as the plaintiff should provide strong evidences to establish the duty of care (Howe, Walsh, \& Rooney, 2012). Duty of care is divided into two parts, one is duty of care for negligent acts, and another is duty of care for negligent advice. The two aspects are quite different.

Duty of care for negligent acts initially uses historical approach, which indicated as 'reasonable foreseeability' and 'proximity'. It could establish a duty of care from the two features. Whilst in the 1990s, the High Court found that historical approach could not include all specific circumstances, and then the contemporary approach began to use (Pentony, Graw, Lennard, \& Parker, 2008). It contained four new issues, including reasonable foreseeability, analogies, neighborhood factors and social policy, which is useful for establishing a duty of care correctly.

For the second essential, breach the standard of care, the courts establish a presumption of a reasonable person which is used to compare with the defendant's conduct in the same circumstances (Richards, Zwart \& Ludlow, 2013). To consider the reasonable person, the courts usually follow two attributes: intelligence, and knowledge and skill. After that the courts have developed several guidelines to help determining the breach in the standard of care. There are five guidelines listed which can clearly figure out the breaches of standards.
As the critical analyzing of the special duty of care, after demonstrate a parent's duty of care to the child and the third party respectively, it provides strong evidences and relevant cases to explain the liability as well. To sum up, firstly a parent owes a duty of care for any negligent acts resulting injury to their child. Secondly, the duty of care may also extend to other people who caring for the child, not only by parents. Thirdly, a parent has no liability for general supervision of their child's actions. However, the duty may arise if the parent either fails to supervise a typically dangerous activity or they cause the damage themselves. Finally, a parent can not liable for their child's tort conducts (Richards, Zwart \& Ludlow, 2013).

\section{ACKNOWLEDGEMENT}

This research was financially supported by the Significant Project on Research Plan of Teaching Quality in Regular Institutions of Higher Education in Tianjin (Grant NO. C03-1102) and the Brand Fields Project of Marketing of Tianjin 12th Five-Year Plan (Grant JinJiaoWeiCai NO. [2011] 61).

\section{REFERENCES}

[1] M. Bagaric, P. Faris, R. Carter, "Torts: Compensation for Harm", in PALGRAVE MACMILLAN, 2011.

[2] J. A. Barravecchio, "The Tort of Negligence", in Legaldate, vol 25, no. 4, 2013.

[3] M. Davies, I. Malkin, Torts, 5th ed., LexisNexis Butterworths, Australia, 2008.

[4] S. W. Howe, G. Walsh, P. Rooney, Torts, 2nd ed., LexisNexis Butterworths, Australia, 2012.

[5] H. Luntz, D. Hambly, Torts: Cases and Commentary, 5th ed., LexisNexis Butterworths, Australia, 2002.

[6] B. Pentony, S. Graw, J. Lennard, D. Parker, Understanding Business Law, 5th ed., LexisNexis Butterworths, Australia, 2008.

[7] B. Richards, K. Ludlow, A. Gibson, TORT LAW IN PRINCIPLE, 5th ed., Thomson Reuters, Australia, 2009.

[8] B. Richards, M.D. Zwart,,K. Ludlow, Tort Law Principles. Thomson Reuters, Australia, 2013.

[9] F. Trindade, P. Cane, M. Lunney, The Law of Torts in Australia, 4th ed., Oxford, New York, 2007. 